\title{
No secret hiding place on the ocular surface: what about after systemic SARS-CoV-2 infection?
}

\author{
Alexander C. RokohI ${ }^{1}$. Gerd Fätkenheuer ${ }^{2,3,4} \cdot$ Claus Cursiefen $^{1,4} \cdot$ Ludwig M. Heindl $^{1}$
}

Received: 26 April 2021 / Revised: 26 April 2021 / Accepted: 28 April 2021 / Published online: 18 May 2021

(c) The Author(s) 2021

\section{Dear Editor,}

In our prospective study, we looked deeply into the possibility that SARS-CoV-2 may hide on the ocular surface of pre-screened asymptomatic patients in a tertiary eye care center [1]. The risk for an isolated conjunctival viral activity in patients with a negative nasopharyngeal swab-based RT-PCR seems to be absent or extremely low, suggesting no need to perform additional conjunctival swabs in patients with negative nasopharyngeal swabs [1].

However, previous studies reported the presence of the entrance receptor of SARS-CoV-2, the angiotensin-converting enzyme 2 (ACE 2), on the ocular surface [2-4]. In addition, SARS-CoV-2 was detected in ocular tissues, tears, and conjunctival secretions of patients with systemic SARSCoV-2 infection [2-4]. Therefore, a potential hiding place on the ocular surface after systemic SARS-CoV-2 infection seems to be possible, especially in patients showing unspecific conjunctivitis during COVID-19 or in patients with ongoing systemic symptoms [4-9]. Furthermore, there is not much known about SARS-CoV-2 on the ocular surface in asymptomatic carriers. These potential hiding places might be a significant risk factor of SARS-CoV-2 transmission to both medical staff as well as other patients $[10,11]$.

This article is part of topical collection on Perspectives on COVID-19

Alexander C. Rokohl

alexander.rokohl@uk.koeln.de

1 Department of Ophthalmology, Faculty of Medicine, University Hospital of Cologne, University of Cologne, Kerpener Straße 62, 50937 Cologne, Germany

2 Department I of Internal Medicine, Division of Infectious Diseases, University of Cologne, Cologne, Germany

3 German Center for Infection Research (DZIF), Partner Site Bonn-Cologne, Cologne, Germany

4 Center for Molecular Medicine Cologne (CMMC), University of Cologne, Cologne, Germany
In addition, the authors raise the very interesting, yet unanswered and clinically highly relevant question of whether SARS-CoV-2 may — as it is known for Ebola virus [12] persist inside the immune-privileged eye even if the patient is otherwise healthy and PCR "negative." This would be compatible with ocular immune privilege [13] and put ophthalmic surgeons and theater personal at risk if ocular surgery is performed even in extraocular "negative" COVID survivors.

Therefore, we fully agree with our highly appreciated colleagues that research regarding other hiding places of SARSCoV-2 within the eye and on the ocular surface should be expanded. The key question of whether long(er) term SARSCoV-2 persistence on the ocular surface and intraocularly of COVID-19 survivors or asymptomatic carriers may hold long-term risks is empirically open. Exploring these concerns using targeted research is now a high priority.

Acknowledgements We thank our highly appreciated colleagues Rafael S. Grajewski, Philomena A. Wawer Matos, Hannah-Leah Koch, Felix Dewald, Florian Klein, and Clara Lehmann for their extraordinary help in this important project.

Funding Open Access funding enabled and organized by Projekt DEAL. Supported by the Gerok Program, Faculty of Medicine, University of Cologne (to A.C.R.), by the Cologne Clinician Scientist Program (CCSP), Faculty of Medicine, University of Cologne, funded by the German Research Foundation (DFG, FI 773/15-1) (to A.C.R), CMMC (A09; to C.C.), DFG FOR 2240 (www.for2240.de; to C.C. and L.M.H.), and EU COST Aniridia (to C.C.). The sponsor or funding organization had no role in the design or conduct of this research. The authors have no further financial disclosures.

\section{Declarations}

Ethics approval and consent to participate All procedures performed in this study involving human participants were in accordance with the ethical standards of the institutional research committee and with the 1964 Helsinki declaration and its later amendments or comparable ethical standards. Institutional Review Board approval was obtained. Informed consent was obtained from all individual participants included in the study. No animal subjects were included in this study. 
Conflict of interest The authors declare no competing interests. All authors have full control of all primary data and they agree to allow to review their data upon request.

Open Access This article is licensed under a Creative Commons Attribution 4.0 International License, which permits use, sharing, adaptation, distribution and reproduction in any medium or format, as long as you give appropriate credit to the original author(s) and the source, provide a link to the Creative Commons licence, and indicate if changes were made. The images or other third party material in this article are included in the article's Creative Commons licence, unless indicated otherwise in a credit line to the material. If material is not included in the article's Creative Commons licence and your intended use is not permitted by statutory regulation or exceeds the permitted use, you will need to obtain permission directly from the copyright holder. To view a copy of this licence, visit http://creativecommons.org/licenses/by/4.0/.

\section{References}

1. Rokohl AC, Grajewski RS, Wawer Matos PA, Koch HL, Dewald F, Klein F, Fatkenheuer G, Lehmann C, Cursiefen C, Heindl LM (2021) No secret hiding place? Absence of SARS-CoV-2 on the ocular surface of 1145 hospitalized patients in a pandemic area. Graefes Arch Clin Exp Ophthalmol. https://doi.org/10.1007/ s00417-021-05086-3

2. Grajewski RS, Rokohl AC, Becker M, Paulsen F, Heindl LM (2021) Malignancy going viral: ACE2 and TMPRSS2 expression in conjunctival neoplastic diseases. Ann Anat 234:151661. https:// doi.org/10.1016/j.aanat.2020.151661

3. Grajewski RS, Rokohl AC, Becker M, Dewald F, Lehmann C, Fatkenheuer G, Cursiefen C, Klein F, Heindl LM (2021) A missing link between SARS-CoV-2 and the eye?: ACE2 expression on the ocular surface. J Med Virol 93:78-79. https://doi.org/10.1002/ jmv.26136

4. Rokohl AC, Loreck N, Wawer Matos PA, Mor JM, Zwingelberg S, Grajewski RS, Cursiefen C, Heindl LM (2020) The role of ophthalmology in the COVID-19 pandemic. Ophthalmologe 117:642-647. https://doi.org/10.1007/s00347-020-01148-9

5. Rokohl AC, Loreck N, Wawer Matos PA, Zwingelberg S, Augustin M, Dewald F, Grajewski RS, Klein F, Lehmann C, Heindl LM
(2020) More than loss of taste and smell: burning watering eyes in coronavirus disease 2019. Clin Microbiol Infect 26(11):e1565e1568. https://doi.org/10.1016/j.cmi.2020.08.018

6. Luers JC, Rokohl AC, Loreck N, Wawer Matos PA, Augustin M, Dewald F, Klein F, Lehmann C, Heindl LM (2020) Olfactory and gustatory dysfunction in coronavirus disease 2019 (COVID-19). Clin Infect Dis 71:2262-2264. https://doi.org/10.1093/cid/ciaa525

7. Luers JC, Rokohl AC, Loreck N, Wawer Matos PA, Augustin M, Dewald F, Klein F, Lehmann C, Heindl LM (2020) Reply to Gourtsoyannis. Clin Infect Dis 71:3018-3019. https://doi.org/10. 1093/cid/ciaa693

8. Guemes-Villahoz N, Burgos-Blasco B, Garcia-Feijoo J, SaenzFrances F, Arriola-Villalobos P, Martinez-de-la-Casa JM, BenitezDel-Castillo JM, Herrera de la Muela M (2020) Conjunctivitis in COVID-19 patients: frequency and clinical presentation. Graefes Arch Clin Exp Ophthalmol 258:2501-2507. https://doi.org/10. 1007/s00417-020-04916-0

9. COVIDSurg Collaborative, GlobalSurg Collaborative (2021) Timing of surgery following SARS-CoV-2 infection: an international prospective cohort study. Anaesthesia. https://doi.org/10.1111/ anae. 15458

10. Saban O, Levy J, Chowers I (2020) Risk of SARS-CoV-2 transmission to medical staff and patients from an exposure to a COVID19-positive ophthalmologist. Graefes Arch Clin Exp Ophthalmol 258:2271-2274. https://doi.org/10.1007/s00417-020-04790-w

11. COVIDSurg Collaborative, GlobalSurg Collaborative (2021) SARS-CoV-2 vaccination modelling for safe surgery to save lives: data from an international prospective cohort study. Br J Surg. https://doi.org/10.1093/bjs/znab101

12. Varkey JB, Shantha JG, Crozier I, Kraft CS, Lyon GM, Mehta AK, Kumar G, Smith JR, Kainulainen MH, Whitmer S, Stroher U, Uyeki TM, Ribner BS, Yeh S (2015) Persistence of Ebola Virus in Ocular Fluid during Convalescence. N Engl J Med 372:24232427. https://doi.org/10.1056/NEJMoa1500306

13. Streilein JW (2003) Ocular immune privilege: therapeutic opportunities from an experiment of nature. Nat Rev Immunol 3:879889. https://doi.org/10.1038/nri1224

Publisher's note Springer Nature remains neutral with regard to jurisdictional claims in published maps and institutional affiliations. 